\title{
ENVIRONMENT ENGINEERING TO MITIGATE ENVIRONMENTAL POLLUTION IN GOA WITH SPECIAL FOCUS ON MINING
}

\author{
Debasis Patnaik, Asst Prof and Head of Deptt of Economics, BITS Pilani, K K Birla Goa Campus \\ Ronit Datta, Research Student, B Tech Chemical Engg, BITS Pilani, K K Birla Goa Campus
}

Located on the West coast and spanning 7000 sq. km, Goa is India's smallest state by area with nearly $38 \%$ of its area is forest. However, it has significant deposits of manganese, bauxite and iron ore. The then Portuguese government handed 700 'mining concessions' to allow people to mine the area. Post liberation, the Government of India cancelled these concessions and provided 'mining leases' under the purview of Indian mining and environmental regulation, in 1987. Despite these measures, the mining industry has grown exponentially - form less than 5 million tonnes in the 1960 's to more than nearly 60 million tonnes in 2011, after which an inquiry into illegal mining by the Shah commission and a supreme court interim ban on all extraction occurred. In April 2014, the ban has been lifted and an annual cap of 20 million tonnes has been placed (Goa foundation - Sweet Land of Mine, 2009).

The main rivers Mandovi and Zuari both flowing into the Arabian sea are navigable by barges used for transporting the ore. Iron ore, Manganese ore, Bauxite are minerals of economic importance. Besides there are minor minerals like Basalt, Laterite stones and rubbles, River sand, Murrum etc., which are in great demand as construction material. This industry is labour intensive and provides work to large number of people. Mining in Goa today is synonymous with iron ore mining.

Present day mining resumed in 1947 which marks the beginning of modern day mining and export of iron ore. The exports have steadily increased from 4,36,400 tonnes of iron ore in 1951 to 35 million tones in 2008-09. The Goan iron ore is exported to China, Japan, Taiwan, South Korea and Eastern European Countries. Iron ore mining in Goa is completely in the private sector. The Iron ore deposits are distributed over the Northern, Southern and Central Blocks of Goa. The Northern Block deposits are richer both in terms of quality and quantity of the ore, as compared to the Southern and Central Blocks. Infrastructure wise Goa has an advantage over other exporting regions in the countries in view of its being endowed with a deep sea port and waterways that crisscross the territory facilitating barge transport. The two rivers Mandovi and Zuari have proved to be a boon to the working industry as they provide cheap river transport. The Bauxite Mines are situated in South Goa over an area of 1263.678 HA. with estimated reserves of 70 million tons. These are metallurgical grade bauxite which can also be used for various applications such as cement, alumina chemicals, etc. The mines are also in the close proximity of two major ports, viz. Marmugoa Port and Betul Port. It has the following Minor Minerals reserves Basalt, Laterite, River sand, Laterite-Rubble, Laterite boulders, Pebble, Murrum and Lime Shell. The Major Minerals reserves are Bauxite, Iron ore, Manganese ore etc.

The mining belt of Goa covers approximately 700 sq. $\mathrm{km}$ and is mostly concentrated in four talukas namely, Bicholim of North Goa district and Salcete, Sanguem and Quepem of South Goa district. Mining and associated activities have greatly affected the natural landscape in and around these areas, which is characterized by the presence of pits and waste rejects. It is divided into three regions based on the concentration of the iron ore, namely, Northern, Central and Southern Zone. Usgao River is the dividing line for northern and central zone and Sanguem River between the central and southern zone. The maximum area under mining is in SanguemTaluka followed by Bicholim, Sattari and Quepem.

Operation mechanism - In Goa, opencast type of mining techniques are used to extract iron/manganese ores. It is carried out by forming systematic benches on the hilltop and along hill slopes and the pits are laterally extended in stages in all directions with increasing depth. In general, bench height and width are maintained at $7 \mathrm{~m}$ and $10 \mathrm{~m}$ respectively. The pit configurations are planned in such a way that the overall pits slopes remains at 30 degree or less with the horizontal. 
Sequence of mining operation involves -

a. Systematic removal of lateritic overburden. Soft Laterite is removed by dozing and ripping. Drilling and blasting is practiced in hard and compact Laterite

b. Extraction of lumpy ore zone followed by powdery ore zone.

c. Wet or dry processing of the mined material so as to attain the desired cut-off grade of the iron ore. (i.e. $62 \%$ of iron) for export purpose.

\section{General Impact on Environment}

Mining has also created a degraded environment and is also a matter of concern. Damage to the environment is mainly done by the reject dumps, pumping out of muddy waters from the working pits including those where the mining operations have gone below the water table, and slimes from the beneficiation plant. The damage is more evidenced during monsoon where the rain water carries the washed out material from the waste dumps to the adjoining low-lying agricultural fields and water streams. It is stated that the slimes and silts, which enter the agricultural field are of such character that they get hardened on drying. The washed out material from the dumps and the flow of slimes from the beneficial plants besides polluting the water causes Siltation of water- ways, especially during monsoon. Such silting of water ways over the years may trigger years even flooding of the adjacent fields and inhabitated areas, especially during monsoon. Several major environmental problems caused due to mining operations are Deforestation, Land degradation, Groundwater pollution, Surface water pollution, Dust pollution,Damage to beaches

Environmental engineering is the integration of sciences and engineering principles to improve the natural environment, to provide healthy water, air, and land for human habitation and for other organisms, and to clean up pollution sites according to Oxford. Environmental engineering can also be described as a branch of applied science and technology that addresses the issue of energy preservation, production asset and control of waste from human and animal activities. Furthermore, it is concerned with finding plausible solutions in the field of public health, such as waterborne diseases, implementing laws which promote adequate sanitation in urban, rural and recreational areas. It involves waste water management and air pollution control, recycling, waste disposal, radiation protection, industrial hygiene, environmental sustainability, and public health issues as well as a knowledge of environmental engineering law. It also includes studies on the environmental impact of proposed construction projects.

Environmental engineers also design municipal water supply and industrial wastewater treatment systems( Beychok, Milton R. (1967) as well as address local and worldwide environmental issues such as the effects of acid rain, global warming, ozone depletion, water pollution and air pollution from automobile exhausts and industrial sources. Turner, D.B. (1994).

Literature review

\section{Remote sensing and GIS for biodiversity studies}

Rocchini, Balkenhol, et. al. (2010) provides a review paper on remotely sensed spectral heterogeneity variation in visual spectra from the images - and their viability of usage as a proxy for species identification. Heterogeneity refers to the variation on a particular scale, and environmental heterogeneity refers to this variation among species, landscapes, habitats and human land-use. The general consensus is that greater environmental heterogeneity means greater number of niches and hence larger number of species. Remote sensingdata sources and techniques are being rapidly developed but quantitative tests need to be carried out to assess diversity usingthese data and techniques. Also, different statistical and map-based modelling procedures that havebeen proposed for predicting biodiversity by remote should not be more complex than the realitythey are seeking to represent. A major problem with spectral heterogeneity as a proxy for diversity is the inability to account for uniqueness or ecological importance of different habitats.

Yadav, P.K., Kapoor M. and Sarma K. (2012) provide a case study for mapping land cover changes from India, specifically the Nagzira- Navegaon corridor in Central India. They used Landsat imagery for the three time periods of 1990, 1999 and 2009, classified the land into dense forest, open forest, water body and non-forest for both the sets and found 
their changes, concentrating on the corridor between two protected habitats. It was found that from 1990 to 1999, a significant part of the forest changed from dense to open forest, probably highlighting insufficient protection. From 1999 to 2009, an opposite trend is seen. The corridor itself was most prone to conversion to non-forest are at the location of roads and other linear projects.

Roy P.S. and Sharma S. (2007) present another case study for such remote sensing-GIS applications from the Central Himalayas. They mapped the fragmentation of forest landscapes within their study area of $5167 \mathrm{sq} . \mathrm{km}$. and found $41 \%$ of that forest was fragmented. They also checked it at various scales, from $75 \times 75 \mathrm{~m}$ to $575 \mathrm{mx} 575 \mathrm{~m}$. Studies have found that at least $40 \mathrm{~m}$ changes are felt in the microclimate from edge effects, thereby rendering literally the whole sample area susceptible to these changes. While the size of fragmentation is very small, the scale of this is alarming throughout the Himalayan region as it can all be classified as highly fragmented.

Menon, S. and Bawa K.S. (1997) perform several analyses - modelling deforestation, biomass estimation, land-use change, fragmentation, and correlation with socioeconomic drivers of land use change. They study two regions of the Western Ghats - the BiligiriRangan Hills and Agastyamalai region. This is one of the first studies in this field of work and hence presents some interesting insight into modelling and methods.

Nagendra, H. and Ostrom E. (2011) perform a metaanalysis of forest-density changes as monitored in sample plots from 53 case studies. They find that while tree changes monitored by the users strongly correlated with randomly distributed forest plots, shrub/sapling changes were less strong. Also, changes are difficult to monitor from field data, and thus local solutions are recommended for monitoring habitats.

Kotha M. and Kunte P.D. (2013) studied Goa's Landcover changes using similar techniques as Roy and Sharma. The looked at 4 different land forms settlement, vegetation, open land and water bodies and found their temporal distribution each decade, over 4 decades. They used Landsat imagery, used GIS to vectorize this data and found the net areas and changes in the same. Other image pre-processing techniques were also used. They found that in the first decade change, the vegetation fell sharply and the settlement area increased considerably, but the subsequent decade, a slight increase in green cover despite a lower but increasing settlement area indicates some afforestation measures. As highlighted in the abstract, this remains a preliminary study, aimed at obtaining base-line information on Goa's landscape.

\section{METHODOLOGY}

\section{Approach and field survey}

The village of Bicholim and the village of Valpoi are taken as locations of study. Bicholim has long been the centre of mining activity in Goa and considered a mining centre. Valpoi is located at the foothills of the ChorlaGhat and has little or no mining activity in the area around it. Moreover, the forested areas around Valpoi are rich in biodiversity and present an interesting case of contrast with the locations in Bicholim.

The price of land in India is set by the government which sets the guidance value. The market value is over and above this guidance value, and there are no official records of the same. Thus, once could either obtain this information from real-estate agents or from the persons involved in the transaction. Due to paucity of contacts in the regions, the author approached the house owners themselves. However, after surveying 5 households, the variance of information collected, specifically land prices was too high to obtain any tangible information. The quoted values of land prices at the time of purchase varied from Rs.400/sq. ft. to Rs.3/sq. ft.! There was difficulty in communicating in English, many didn't remember the rates and/or had no access to official rates. Most importantly, people were sceptical about revealing information, especially since we the issue of mining was sensitive in the area with the Goan public divided in their opinion of the same, and the people near mines bearing the brunt of the economic burden from the mining ban.

Thus the methodology involved created a framework for this analysis with more reliable land prices obtained later. Therefore, the spatial attributes table of distances from different land use variables from each household was obtained. 
Proc. of the Sixth Intl. Conf. Advances in Bio-Informatics, Bio-Technology and Environmental Engineering- ABBE 2018 Copyright $(\odot$ Institute of Research Engineers and Doctors, USA. All rights reserved.

ISBN: 978-1-63248-148-1 doi: 10.15224/978-1-63248-148-1-38

\section{GIS analysis}

Each Taluka in Goa is divided into villages, and the delimitation of these villages has been obtained from the village maps as a part of the 2021 Goa Regional Plan, accessed in the Goa Files website (goafiles.com, hosted by BITS-Pilani professor Dr.Solano and available for free). Bicholim and Sattari are the two Talukas, and Bicholim village and Valpoi villages are the two villages from the respective talukas that have been considered for this study.

The regional plan also specifies the different classification of land - as agricultural land, commercial land, mining area, protected area, etc., apart from roads, prominent locations, rivers, and also numbered plots.

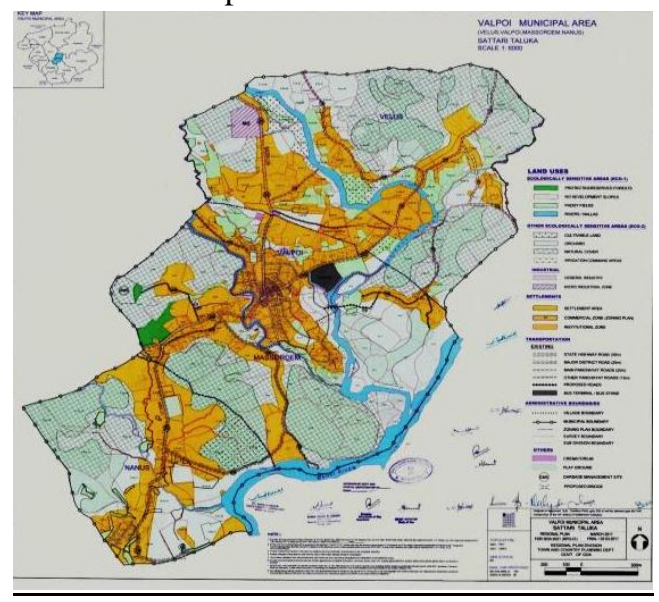

Fig1. VALPOI VILLAGE, SATTARI TALUKA (Source: goafiles.com)

All these landscape features were converted into a vector map of the same. Only the different land use types were found out. The vector image is shown below -

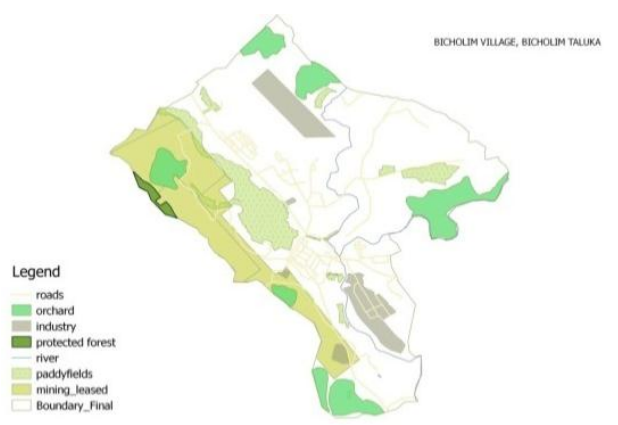

VALPOI MAP DETAILS*

\begin{tabular}{|lrr|}
\hline Type of Land-use & Area in km2 & \% of total area \\
\hline Built up area & 3.61338598 & 29.37335064 \\
\hline Roads & 0.620898563 & 5.047307791 \\
\hline Vegetation & 6.258476527 & 50.87539125 \\
\hline protected area & 0.068695487 & 0.558428199 \\
\hline $\begin{array}{l}\text { Non-Development } \\
\text { Slopes }\end{array}$ & 2.360105226 & 19.18538421 \\
\hline Mhadei River & 0.889560068 & 7.231267275 \\
\hline Agriculture & 1.265262191 & 10.28536397 \\
\hline
\end{tabular}

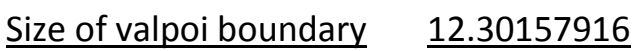

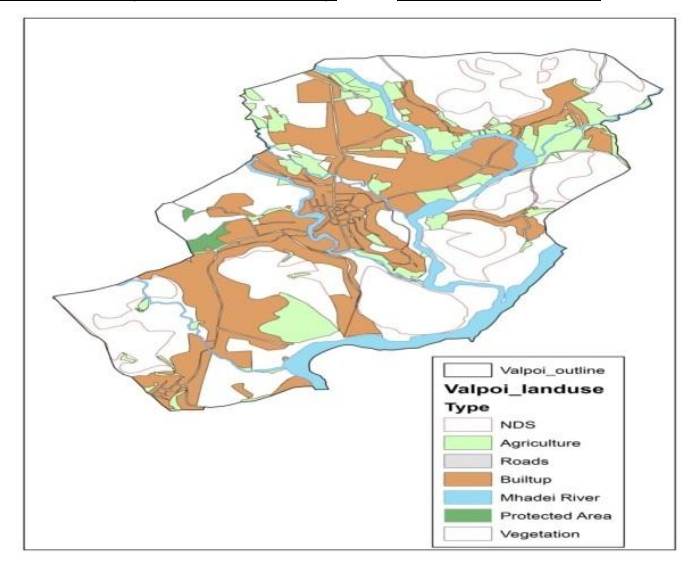

* - Land-use overlap and hence do not add up to size of boundary

Similarly, the Bicholim village and the corresponding

Bicholim vector image

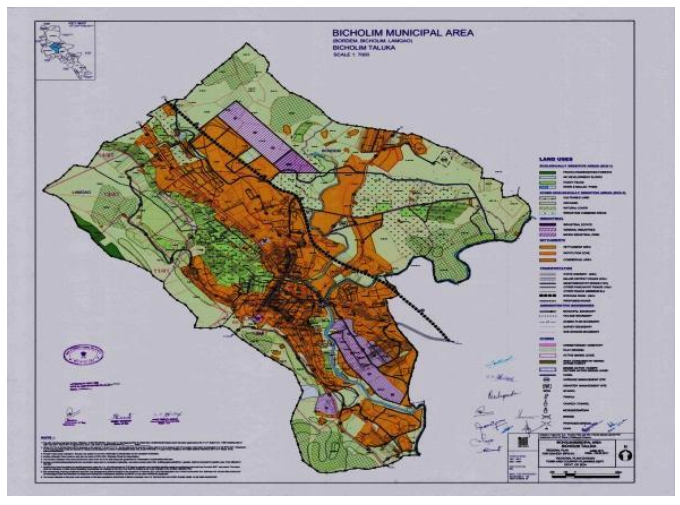

Vector image - 


\section{BICHOLIM MAP DETAILS*}

\begin{tabular}{|lcr|}
\hline Type of Land-use & Area in km2 & $\begin{array}{l}\text { \% of total } \\
\text { area }\end{array}$ \\
\hline Area under mining lease & 2.571741897 & 17.57581249 \\
\hline Industrial area & 0.831651241 & 5.683675443 \\
\hline Vegetation & 1.380255309 & 9.43294836 \\
\hline protected area & 0.077588905 & 0.530258515 \\
\hline Non-Development Slopes & 0.732408532 & 5.005430383 \\
\hline Built-up area & 7.947848742 & 54.31723121 \\
\hline Agriculture & 1.090784239 & 7.454643596 \\
\hline
\end{tabular}

Size of Bicholim boundary 14.63227886

* - Land-use overlap and hence do not add up to size of boundary

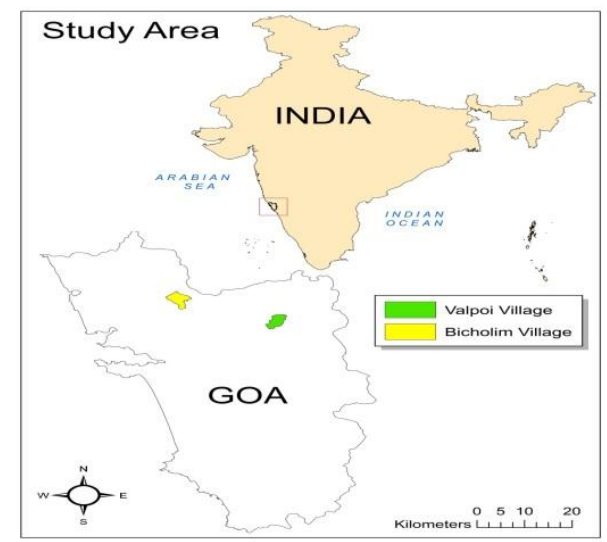

\section{RESULTS}

Bicholim is mainly a mining taluka but one would expect that the mining will stay far from the residential area. However, one can see that $17 \%$ of the village's area is under active mining lease, and the location of the mines is $124 \mathrm{~m}$ from the nearest settlement. This indicates that in regions where the economic effects of mining are significant, the environmental and health diseconomies are neglected by the people concerned. This observation is also buttressed by the field survey where all people living very close to the mines in Lamgoa, Bicholim answered that there were negatives of mining but the positive impact it had on livelihoods were also significant.

One must also note that while $17 \%$ of the area is leased for mining, all area is not mined. Several agricultural areas lie within these leased areas, and so do forests, including protected areas. Even settlements can be found inside these areas, separated by a non-development slope region.

For the village of Valpoi, it is found that while like Bicholim (50\%) it too has a large built-up area (29\%), the amount of forested area (vegetation and non-development slopes) forms a significant $69 \%$. The forested area in Bicholim (including vegetation, non-development slopes and protected area) include just $14.5 \%$. A key difference is that $0.5 \%$ of this forest is protected while none of the forests in Valpoi - classified as vegetation and non-developmental slopes is protected. In terms of agriculture, Valpoi has a little much area under agricultural cultivation than Bicholim, (10\% and 7\% respectively) but the corresponding built-area is significantly smaller.

In the field survey conducted, the land pieces was bought between 1975 and1992. The average household numbered 4.6, the average number of trees per plot was 17.5 trees, the average size of each plot was 675 sq. m. (approximately $120 \mathrm{ft} \times 60 \mathrm{ft}$ ) and the average number of rooms was 3. All field correspondents reported a positive effect of mining on the livelihood people and all of them also reported a negative impact of mining on air quality. Health and water quality had either worsened or remained the same while mining seemed ot have no effect on civic amenities, they felt. 


\begin{tabular}{|c|c|c|c|c|c|}
\hline $\begin{array}{l}\text { House } \\
\text { no. }\end{array}$ & $\begin{array}{l}\text { Impact } \\
\text { on } \\
\text { water } \\
\text { quality }\end{array}$ & $\begin{array}{l}\text { Impact on } \\
\text { livelihood }\end{array}$ & $\begin{array}{l}\text { Impact } \\
\text { on civic } \\
\text { amenities }\end{array}$ & $\begin{array}{l}\text { Impact } \\
\text { on air } \\
\text { quality }\end{array}$ & $\begin{array}{l}\text { Impact } \\
\text { on } \\
\text { Health }\end{array}$ \\
\hline 1 & -ve & $+\mathrm{ve}$ & $\begin{array}{l}\text { No } \\
\text { change }\end{array}$ & $\begin{array}{l}\text { No } \\
\text { change }\end{array}$ & $\begin{array}{l}\text { No } \\
\text { change }\end{array}$ \\
\hline 2 & - ve & $+\mathrm{ve}$ & $-\mathrm{ve}$ & $-\mathrm{ve}$ & - ve \\
\hline 3 & - ve & $+\mathrm{ve}$ & $+\mathrm{ve}$ & - ve & $\begin{array}{l}\text { No } \\
\text { change }\end{array}$ \\
\hline 4 & $\begin{array}{l}\text { No } \\
\text { change }\end{array}$ & $+\mathrm{ve}$ & $\begin{array}{l}\text { No } \\
\text { change }\end{array}$ & - ve & $-\mathrm{ve}$ \\
\hline 5 & $\begin{array}{l}\text { No } \\
\text { change }\end{array}$ & $+\mathrm{ve}$ & $\begin{array}{l}\text { No } \\
\text { change }\end{array}$ & - ve & - ve \\
\hline
\end{tabular}

The prices quoted varied from Rs.13 per sq $\mathrm{m}$, to Rs.400 per sq. m, and the information was deemed unreliable for these numbered varied too much, and were counter intuitive - the price of plot 4 was reported as Rs.13/- when it was bought in 1983 but the price of patches bought in 1982 and 1975 - much before plot 4 - were priced Rs. 100 and Rs.400 respectively. Also, all these survey plots were from the same neighbourhood of Lamgao, and hence the variability was difficult to not attribute to interviewee bias. Since the prices were also rounded to the nearest hundred (usually), it seemed like the residents had no exact memory of the prices, and thus heightening our margin of error.

The opinion of the interviewed residents was fairly uniform on the impacts of mining.

\section{QUESTIONAIRE:}

The following question were made to the people in the bicholim mining area regarding their livelihood and how mining has affected them $\underline{\text { Behavioural questions - Impact of mining }}$

\section{REFERENCES}

1. Menon S. and Bawa K.S. (1997), "Application of GIS, remote-sensing and landscape ecology approach to biodiversity conservation in the Western Ghats", Current Science, Vol. 13. No. 2.

2. Kotha M. and Kunte P.D. (2013), "Land-cover change in Goa - An Integrated RS-GIS approach", International Journal of Geoinformatics, Vol. 9, No. 2.

3. Yadav P.K., Sarma K. and Dookia S. (2013), "The Review of Biodiversity and Conservation study in India using Geospatial Technology", International Journal of remote Sensing and GIS, Vol. 2, Issue 1.

4. Yadav P.K., Mohnish Kapoor, SarmaKiranmay (2012),

"Land Use Land cover mapping, change detection and conflict analysis of Nagzira-Navegaon Corridor, Central India using geospatial technology", International Journal of remote Sensing and GIS, Vol. 1, Issue 2.

5. 5- Nuss, P. and M.J. Eckelman. 2014. Life Cycle Assessment of Metals: A Scientific Synthesis. PLoS ONE 9(7): e101298. http://www.plosone.org/article/info\%3Adoi\%2F10.1371\%2F journal.pone. 0101298

6. 6-Maest et al 2006. Predicted Versus Actual Water Quality at Hardrock Mine Sites: Effect of Inherent Geochemical and Hydrologic Characteristics.

7. 7- B C Jung, Myung Chae; Thornton, Iain (1996). "Heavy metals contamination of soils and plants in the viscinity of a lead-zinc mine, Korea". Applied Geochemistry 11: 53-59.

8. 8-B Diehl, E; Sanhudo, C. E. D; DIEHL-FLEIG, Ed (2004). "GROUND-DWELLING ANT FAUNA OF SITES WITH HIGH LEVELS OF COPPER". Brazilian Journal of Biology 61 (1): 33-39.

9. 9- Tarras-Wahlberga, N.H.; Flachier, A.; Lanec, S.N.; Sangforsd, O. (2001). "Environmental impacts and metal exposure of aquatic ecosystems in rivers contaminated by small scale gold mining: the Puyango River basin, southern Ecuador". The Science of the Total Environment 278: 239261.

10. 10-B Pyatt, F. B.; Gilmore, G.; Grattan, J. P.; Hunt, C. O.; McLaren, S. (2000). "An Imperial Legacy? An Exploration of the Environmental Impact of Ancient Metal Mining and 
Smelting in Southern Jordan". Journal of Archaeological Science 27: 771-778.

11. 11-Mummey, Daniel L.; Stahl, Peter D.; Buyer, Jeffrey S. (2002). "Soil microbiological properties 20 years after surface mine reclamation: spatial analysis of reclaimed and undisturbed sites". Soil biology and chemistry 34: 17171725 .

12. 12- Steinhauser, Georg; Adlassnig, Wolfram; Lendl, Thomas; Peroutka, Marianne; Weidinger, Marieluise; Lichtscheidl, Irene K.; Bichler, Max (2009). "Metalloid Contaminated Microhabitats and their Biodiversity at a Former Antimony Mining Site in Schlaining, Austria". Open Environmental Sciences, 3: 26-41.

13. 13-Niyogi, Dev K.; William M., Lewis Jr.; McKnight, Diane M. (2002). "Effects of Stress from Mine Drainage on Diversity, Biomass, and Function of Primary Producers in Mountain Streams". Ecosystems (5): 554-567.

14. 14-Ek, A. S.; Renberg, I. (2001). "Heavy metal pollution and lake acidity changes caused by one thousand years of copper mining at Falun, central Sweden". Journal of paleolimnology26 (1): 89-107.

15. 15-B- MALMQVIST, BJOÈ RN; HOFFSTEN, PER-OLA (1999). "INFLUENCE OF DRAINAGE FROM OLD MINE DEPOSITS ON BENTHIC MACROINVERTEBRATE COMMUNITIES IN CENTRAL SWEDISH STREAMS". Water Research 33 (10): 2415-2423.

16. 16-Wong, H.K.T; Gauthier, A.; Nriagu, J.O. (1999). "Dispersion and toxicity of metals from abandoned gold mine tailings at Goldenville, Nova Scotia, Canada". Science of The Total Environment 228 (1): 35-47.

17. 17- del Pilar Ortega-Larrocea, Marı; Xoconostle-Cazares, Beatriz; Maldonado-Mendoza, Ignacio E.; Carrillo-Gonzalez, Rogelio; Hernandez-Hernandez, Jani; Diaz Garduno, Margarita; Lopez-Meyer, Melina; Gomez-Flores, Lydia; del Carmen A. Gonzalez-Chavez, Ma. (2010). "Plant and fungal biodiversity from metal mine wastes under remediation at Zimapan, Hidalgo, Mexico". Environmental Pollution 158: 1922-1931.

18. 18-Rösner, T.; van Schalkwyk, A. (2000). "The environmental impact of gold mine tailings footprints in the Johannesburg region, South Africa". Bulletin of Engineering Geology and the Environment 59: 137-148.

19. 19=-Hoostal, MJ; Bidart-Bouzat, MG; Bouzat, JL (2008). "Local adaptation of microbial communities to heavy metal stress in polluted sediments of Lake Erie". FEMS Microbiology Ecology 65: 156-168. 